\title{
Soil Suppressiveness to Fusarium Disease Following Organic Amendments and Solarization
}

Eyal Klein, Laboratory for Pest Management Research, Institute of Agricultural Engineering, ARO, The Volcani Center, Bet Dagan 50250, Israel, and Department of Plant Pathology and Microbiology, The Hebrew University of Jerusalem, The Robert H. Smith Faculty of Agriculture, Food, and Environment, Rehovot 76100, Israel; Jaacov Katan, Department of Plant Pathology and Microbiology, The Hebrew University of Jerusalem, The Robert H. Smith Faculty of Agriculture, Food, and Environment; and Abraham Gamliel, Laboratory for Pest Management Research, Institute of Agricultural Engineering, ARO, The Volcani Center, Bet Dagan 50250, Israel

\begin{abstract}
Klein, E., Katan, J., and Gamliel, A. 2011. Soil suppressiveness to Fusarium disease following organic amendments and solarization. Plant Dis. 95:1116-1123.

Soil suppressiveness to soilborne pathogens can evolve following the incorporation of plant residues in the soil and solarization. We studied its occurrence by assessing disease incidence and severity in sandy soil which was infested after the disinfestation treatment. Disease incidence and severity of crown and root rot in cucumber plants inoculated with Fusarium oxysporum f. sp. radicis-cucumerinum macroconidia were reduced by 20 to $80 \%$ when seedlings were planted in the tested soils 2 to 34 months after soil amendment. Residues of Diplotaxis tenuifolia (wild rocket [WR]), Artemisia dracunculus (tarragon), Salvia officinalis (sage), and Brassica oleracea var. italica (broccoli) were most effective for inducing soil suppressiveness. Effective soil suppressiveness continued to be evident after repeated inoculations and plantings in the same soil without additional treatment between inoculations.

tional tested soils differing in their physical and chemical properties. Residues of Rosmarinus officinalis (rosemary), Coriandrum sativum (coriander), Mentha piperita (peppermint), and B. oleraceae var. botrytis (cauliflower) induced disease suppression at the first inoculated planting but not upon repeated inoculation and planting. The contribution of soil solarization to the evolution of soil suppressiveness, albeit evident, was inconsistent. Soil suppressiveness to Fusarium crown and root rot was also observed when cucumber seed were sown in soils which were initially amended with WR residues and later infested with F. oxysporum f. sp. radicis-cucumerinum chlamydospores. There is a potential for the use of plant residues for inducing soil suppressiveness and further contributing to the control of diseases caused by soilborne pathogens.
\end{abstract} Moreover, residues of WR induced soil suppressiveness in two addi-
Organic amendments (OAs) from various sources (e.g., plant debris, organic waste, or compost) are added to the soil for the control of soilborne pathogens $(6,8,20)$. Among these, crop residues, including crude organic material such as green manure and vegetative plant debris (stem, root, leaves, and so on), can be suitable for the control of soilborne pathogens $(28,29,46)$. Bonanomi et al. (6) reviewed the contribution of soil amendment with crop residues and reported variable responses in controlling soilborne pathogens. In $45 \%$ of the reviewed articles, significant pathogen control and suppressiveness, mainly of Fusarium spp., Verticillium dahliae, Thielaviopsis basicola, and Phytophthora spp., were reported. However, in $28 \%$ of the reviewed articles, increased disease incidence and conduciveness were reported following OA (6). Hence, selecting the appropriate OA is crucial to achieving effective longterm pathogen control and sustainable management of soil quality and health (1). Various biological $(7,12,24)$ or chemical and physical $(5,31,47)$ mechanisms are potentially involved in the decomposition of OAs and in the related processes of pathogen control, disease management, and the development of soil suppressiveness to reinfestation and disease suppression. In a previous work, we found that solarization of soil amended with herb residues improves the disinfestation efficacy against soilborne pathogens $(28,29)$.

Corresponding author: A. Gamliel, E-mail: agamliel@agri.gov.il

Contribution number 720/10 series from the Agricultural Research Organization, The Volcani Center, Bet Dagan, Israel.

Accepted for publication 11 May 2011.

doi:10.1094/PDIS-01-11-0065

(C) 2011 The American Phytopathological Society
Soil suppressiveness is defined as the soil's ability to detain disease onset in a susceptible host, even in the presence of a significant inoculum density of the pathogen (12). In suppressive soils, disease incidence or severity usually remain low, even under environmental conditions that favor disease development (12). Disease suppressiveness and pathogen suppressiveness are not necessarily the same thing, because reduction in disease incidence and severity is not always the result of a direct effect on the pathogen. Soil suppressiveness-namely, capacity of the soil to suppress reinfestation by a pathogen introduced into the soil after treatment - can evolve following various soil treatments, including incorporation of OAs $(11,21,38,48,51)$, but also by other agrotechnical means such as soil cultivation, monoculture, or crop rotation (12,39,47). Longterm soil suppressiveness against certain pathogens has been reported to evolve in some cases following soil solarization $(18,19,22,33)$. In contrast to the many studies which have demonstrated disease control by OAs combined with soil solarization $(16,29,43)$, only a few studies have dealt with their effects on soil suppressiveness.

The mechanism of pathogen control following amendment with certain OAs and the evolution of soil suppressiveness might be related. OA decomposition in the soil induces shifts in chemical and physical conditions and in soil microbial populations and activities. The new microbial balance might be involved in the suppression of pathogen reinfestation and delay of disease onset in future cropping. The objective of this work was to assess soil suppressiveness by soil amendments with residues from herb and other plants, with or without solarization, and its potential to suppress a disease caused by a soilborne pathogen introduced into the soil following the treatment.

\section{Materials and Methods}

Soil and OAs. Soil samples were collected from three agricultural field sites in different locations in Israel. Two types of soil 
were used: sandy soil from Rehovot, in the center of Israel (94\% sand, $2 \%$ silt, $4 \%$ clay, $0.12 \%$ organic matter, $\mathrm{pH} 7.9$, field capacity of $9 \%$, measured at $-33 \mathrm{~J} / \mathrm{kg}$ matric potential); sandy soil from En Tamar, which was collected from the southern desert, in the Arava region ( $89 \%$ sand, $7 \%$ silt, $4 \%$ clay, $0.1 \%$ organic matter, $\mathrm{pH}$ 8.1 , field capacity of $8 \%$ ); and loamy soil from Bet Dagan, in the center of Israel $(22.5 \%$ sand, $25 \%$ silt, $52.5 \%$ clay, $1.4 \%$ organic matter, $\mathrm{pH} 7.5$, field capacity of $20 \%$ ). These soils represent the range of agricultural soils in Israel (50). The soils had no history of soil disinfestation or fumigation for at least 5 years prior to sampling. Several samples were collected from the upper layer (5- to $20-\mathrm{cm}$ depth) of the soil. For each site, the soil samples (total of $500 \mathrm{~kg}$ ) were mixed into one large composite sample, air dried, and sieved through a $1-\mathrm{mm}$ screen. The soils were stored in plastic containers at room temperature pending use (up to 4 weeks after collection).

Leaves and stem debris of the following plants were tested: Salvia officinalis L. (sage), Rosmarinus officinalis L. (rosemary), Coriandrum sativum L. (coriander), Diplotaxis tenuifolia (L.) DC. (wild rocket [WR]), Mentha piperita L. (peppermint), Brassica oleracea L. var. italica (broccoli), B. oleraceae L. var. botrytis (cauliflower), and Artemisia dracunculus L. (tarragon). The foliage of these crops was collected from commercial agricultural fields during crop production. The leaves and stems of each crop were separately air dried at $25^{\circ} \mathrm{C}$, then ground and sieved through a 2$\mathrm{mm}$ sieve. The sieved residues of each plant species were used as OAs.

Soil amendment. The specified dried and ground crop residues were incorporated into $20 \mathrm{~kg}$ of soil sample at a rate of 1 or $2 \%\left(\mathrm{wt} / \mathrm{wt}\right.$ ), as indicated (equivalent to a rate of 1 or $2 \mathrm{~kg} / \mathrm{m}^{2}$ in the field, respectively; 28). The soil-amendment mixture was wetted to water-holding capacity. Each amended soil mixture was packed in a porous, woven plastic bag (total of $22 \mathrm{~kg} / \mathrm{bag}$ ). Nonamended soil was prepared and packed similarly and served as the control.

Incorporation of amended soil and soil solarization in small field plots. Small field-plot experiments were conducted during the summer in 2005 through 2009, at the experimental farm of the Hebrew University in Rehovot. In each year, the field was rotovated to $50-\mathrm{cm}$ depth and then irrigated to water-holding capacity down to $50 \mathrm{~cm}$. Plots $(2$ by $4 \mathrm{~m})$ were outlined and trenches $(20 \mathrm{~cm}$ deep) were dug in the margins of each plot. Porous plastic bags containing the amended soils were buried horizontally and flat in the center of each plot, in a layer 10 to $30 \mathrm{~cm}$ below the soil surface. The treatments included four combinations of soil amendments and solarization; in each plot, the respective soil mixture was buried. All plots were mulched with a transparent polyethylene sheet (100 $\mu \mathrm{m}$ thick). Nonsolarized plots were additionally covered with a shading screen (90\% shade; Polysak, Nir Itzhak, Israel) which was laid over the plastic mulch to avoid soil heating and solarization. Each experiment was set up in a randomized block design, with three replicates for each treatment. The solarized plots were exposed to solarization for a period of 28 days during the months of July or August, as indicated. Soil temperatures were recorded at a depth of $20 \mathrm{~cm}$, using type-T thermocouples (accuracy $\left.\pm 0.5^{\circ} \mathrm{C}\right)$ connected to a micrologger $(21 \mathrm{X}$; Campbell Scientific Inc., Logan, UT). Soil temperature reached 34 to $48.7^{\circ} \mathrm{C}$ at $20 \mathrm{~cm}$ in the solarized plots, compared with 32 to $34^{\circ} \mathrm{C}$ in the shaded, nonsolarized plots. Upon termination of the solarization period, the plastic sheets were removed from the plots and the soil bags with their contents were brought to the laboratory and allowed to air dry at $25^{\circ} \mathrm{C}$ for 1 month prior to their use. In certain cases, the soils were stored for extended periods in the shade at room temperature.

Plant inoculation and disease suppressiveness assay. Fusarium oxysporum f. sp. radicis-cucumerinum Vakal., the causal agent of cucumber root and crown rot disease, was used as the bioassay organism. Infected cucumber plants were collected from a commercial cucumber greenhouse and the stems, containing macroconidia of $F$. oxysporum $\mathrm{f}$. sp. radicis-cucumerinum in their lower section, were used for the suppressiveness tests. Isolates of $F$. oxysporum f. sp. radicis-cucumerinum were taken from each stem and tested for pathogenicity using cucumber seedlings prior to their selection for the suppressiveness assays, to validate their identity as $F$. oxysporum $\mathrm{f}$. sp. radicis-cucumerinum. The macroconidia of this pathogen, as a natural inoculum, were scraped into sterile water and their density was adjusted to the desired concentration with the aid of a hemacytometer. Macroconidia were assessed prior to each assay using a soil-dilution-plating technique (28). Suspensions of macroconidia which showed at least $80 \%$ germination after $24 \mathrm{~h}$ were used for the suppressiveness tests.

Soil suppressiveness assays in which inoculated seedlings were planted in previously treated soils were conducted in pot experiments essentially as previously reported (51). Pots (0.45-liter, 0.5 $\mathrm{kg}$ each) were filled with soil taken from the various aforedescribed soil-amendment treatments. One day before the experiment, the soil in the pots was irrigated to water-holding capacity. Seed of cucumber (Cucumis sativus L. 'Kfir') were sown in sandy soil. Six-day-old seedlings were removed and their roots were washed, then dipped for $2 \mathrm{~min}$ in a suspension of $F$. oxysporum f. sp. radicis-cucumerinum macroconidia, adjusted to the indicated density. The inoculated seedlings were then transplanted into pots which were filled with soil taken from the various soil-amendment treatments. For each treatment, five pots were planted with seven inoculated seedlings per pot and repeated planting cycles were conducted at least twice. An additional pot was planted with noninoculated seedlings and served as a control. All trials were arranged in the greenhouse $\left(24-27^{\circ} \mathrm{C}\right)$ in a complete randomized-block design.

Disease symptoms in cucumber seedlings usually appear 7 days after inoculation and are manifested as wilt and plant collapse. Disease progress was expressed as percentage of diseased plants, area under the disease-progress curve (AUDPC; 9), and, when indicated, percentage of the value of the AUDPC relative to the inoculated control. The noninoculated plants remained healthy in all experiments. A reduction in disease incidence or severity in amended soil compared with nonamended soil reflected soil suppressiveness, because the plants were inoculated and introduced into the soil after the OA and solarization treatments had been terminated (i.e., the pathogen was not exposed to a direct control process). Soil suppressiveness was observed during the first planting cycle in which the pathogen was initially introduced. It was further evident after repeated planting and inoculations which surpassed the population of $F$. oxysporum f. sp. radicis-cucumerinum which existed in the soil from the previous planting.

In certain experiments (Table 1), inoculated cucumber seedlings were repeatedly planted in the same pots to examine the long-term effect of the suppressiveness. In these experiments, all plants from the previous assay were removed and the pots were left to dry for a week. The pots were then irrigated to field capacity, followed by a second disease-suppression assay as already described.

In a few specific experiments, chlamydospores were used as inoculum. Chlamydospores were produced on peat (Plantobalt, peat moss, degree of decomposition $\mathrm{h} 2$ to $\mathrm{h} 5, \mathrm{pH} 2.5$ to 3.5 , water-holding capacity 55 to $75 \%$, Estonia and Latvia) which was steam sterilized and inoculated with an $F$. oxysporum f. sp. radicis-cucumerinum macroconidia suspension. The inoculated peat was incubated in the dark at $25^{\circ} \mathrm{C}$, and viability of $F$. oxysporum f. sp. radicis-cucumerinum propagules was assessed at 30-day intervals for 3 months, until inoculum density stabilized at $4.075 \times 10^{6}$ $\mathrm{CFU} / \mathrm{g}$ peat. Inoculum density and viability were assessed using the soil-dilution-plating technique described for the macroconidia The infested peat was used as a source of $F$. oxysporum $\mathrm{f}$. sp. radicis-cucumerinum inoculum in the soil by incorporating it with the tested soil at a rate of 1,2 , or $5 \%(\mathrm{wt} / \mathrm{wt})$. Eight cucumber seeds were planted into each pot.

Statistical analyses. All experiments were carried out at least twice, yielding similar results, except for the experiment in which the long-term effect was assessed, which was carried out only once but with three repeat-inoculation plantings. Separate analyses of 
each experiment showed homogeneous variance of the experimental error between repetitions. Data were first analyzed by analysis of variance (ANOVA) to test for possible interaction among the main effects, followed by the appropriate mean separation analysis using Tukey's studentized range (honestly significant difference) test. All analyses were performed with SAS software (release 9.1 for PC; SAS Institute, Cary, NC) with significance at $P \leq 0.05$.

\section{Results}

Suppression of Fusarium crown and root rot in cucumber plants by crop residues and soil solarization. Disease suppression in cucumber seedlings which were artificially inoculated with F. oxysporum f. sp. radicis-cucumerinum was evident when they were planted in soil previously amended with residues of all of the tested plants, compared with the respective nonamended soils (Figs. 1 and 2; Tables 1 and 2). There were, however, differences among the various plant residues with respect to their potential for suppressiveness, with coriander and WR inducing the greatest level of suppressiveness. Solarization did not further contribute to the suppressiveness observed with the use of crop residues alone (Figs. 1 and 2; Tables 1 and 2). A typical example of suppressiveness as reflected by disease progress and AUDPC is given in Figure 1. Increases in growth parameters resulting from soil amendment are shown in Table 3. In nonamended soil, disease symptoms (chlorosis, plant-growth retardation, and wilt) first appeared 7 to 10 days after inoculation, reaching 60 to $100 \%$ plant mortality 21 days after inoculation. In the WR-amended soils, disease symptoms usually appeared 1 to 7 days later and plant mortality was reduced by 20 to $80 \%$. Root and shoot dry weights were significantly higher in both inoculated and noninoculated WR-amended soil compared with the respective nonamended soils (Table 3 ). Increasing WR concentration from 1 to $2 \%$ in the amended soil did not significantly add to the soil's suppressiveness to the disease (results not shown); disease incidence was 90 and 50\% lower than in nonamended soil $(P$ $<0.0001)$ at both WR concentrations in the first and second inoculated planting, respectively.

Disease suppressiveness following repeated inoculation. The manifestation of disease suppressiveness was examined over two or three consecutive inoculation and planting cycles in the same pots. Disease incidence was significantly reduced in the soils which had been previously amended with WR, peppermint, broccoli, sage, or tarragon compared with the nonamended soils, throughout the consecutive planting cycles (Tables 1 and 2; Figs. 2-4). In contrast, solarization, in general did not sustain significant suppressive capacity and, in some cases, increased disease incidence was observed in the second or third planting cycle with many of the tested crops (Tables 1 and 2; Fig. 2). However, in one experiment, tarragon combined with solarization sustained suppressiveness capacity during the second and third crop cycles relative to either tarragon or solarization alone (Fig. 3). Sup-

Table 1. Effect of organic amendments and solarization on area under the disease progress curve (AUDPC) of Fusarium crown and root rot in inoculated cucumber seedlings in Rehovot soil ${ }^{\mathrm{x}}$

\begin{tabular}{|c|c|c|c|c|c|}
\hline \multirow[b]{2}{*}{ Experiment $^{\mathrm{z}}$} & \multirow[b]{2}{*}{ Amendment } & \multicolumn{2}{|c|}{ AUDPC, first planting ${ }^{y}$} & \multicolumn{2}{|c|}{ AUDPC, second planting ${ }^{y}$} \\
\hline & & Shaded & Solarized & Shaded & Solarized \\
\hline 1 & Nonamended & $738.6 \mathrm{~A}$ & $597.1 \mathrm{~A}$ & $538.6 \mathrm{~A}$ & $447.1 \mathrm{~A}$ \\
\hline 1 & Coriander & $125.7 \mathrm{C}$ & $128.6 \mathrm{~B}$ & $547.1 \mathrm{~A}$ & $644.3 \mathrm{~A}$ \\
\hline 1 & Peppermint & $370.0 \mathrm{~B}$ & $199.0 \mathrm{~B}$ & $261.4 \mathrm{~B}$ & $484.3 \mathrm{~A}$ \\
\hline 1 & Rosemary & $278.6 \mathrm{~B}$ & $250.0 \mathrm{~B}$ & $455.7 \mathrm{AB}$ & $604.3 \mathrm{~A}$ \\
\hline 2 & Nonamended & $825.7 \mathrm{~A}$ & $640.0 \mathrm{~A}$ & $788.6 \mathrm{~A}$ & $765.7 \mathrm{~A}$ \\
\hline 2 & Broccoli & $333.6 \mathrm{~B}$ & $202.1 \mathrm{~B}$ & $531.2 \mathrm{AB}$ & 473.8 B \\
\hline 2 & Cauliflower & $284.1 \mathrm{~B}$ & $280.1 \mathrm{~B}$ & $530.0 \mathrm{AB}$ & $672.9 \mathrm{AB}$ \\
\hline 2 & Sage & 639.3 B & $218.3 \mathrm{~B}$ & 241.1 B & $195.7 \mathrm{C}$ \\
\hline
\end{tabular}

${ }^{\mathrm{x}}$ Cucumber seedlings were inoculated with Fusarium oxysporum f. sp. radicis-cucumerinum macroconidia at $1.5 \times 10^{5} \mathrm{CFU} / \mathrm{ml}$ and planted in the previously treated soils. For each experiment, values within a column followed by different letters are significantly different according to Tukey's studentized range (honestly significant difference) test at $P \leq 0.05$.

${ }^{\mathrm{y}}$ Solarization or shading under field conditions was conducted for 28 days during July 2005. Plant residues were applied to the soil at $10 \mathrm{~g} / \mathrm{kg}(1 \%$, wt/wt).

${ }^{\mathrm{z}}$ Data from each experiment represent the combined analysis of two trials that were pooled.
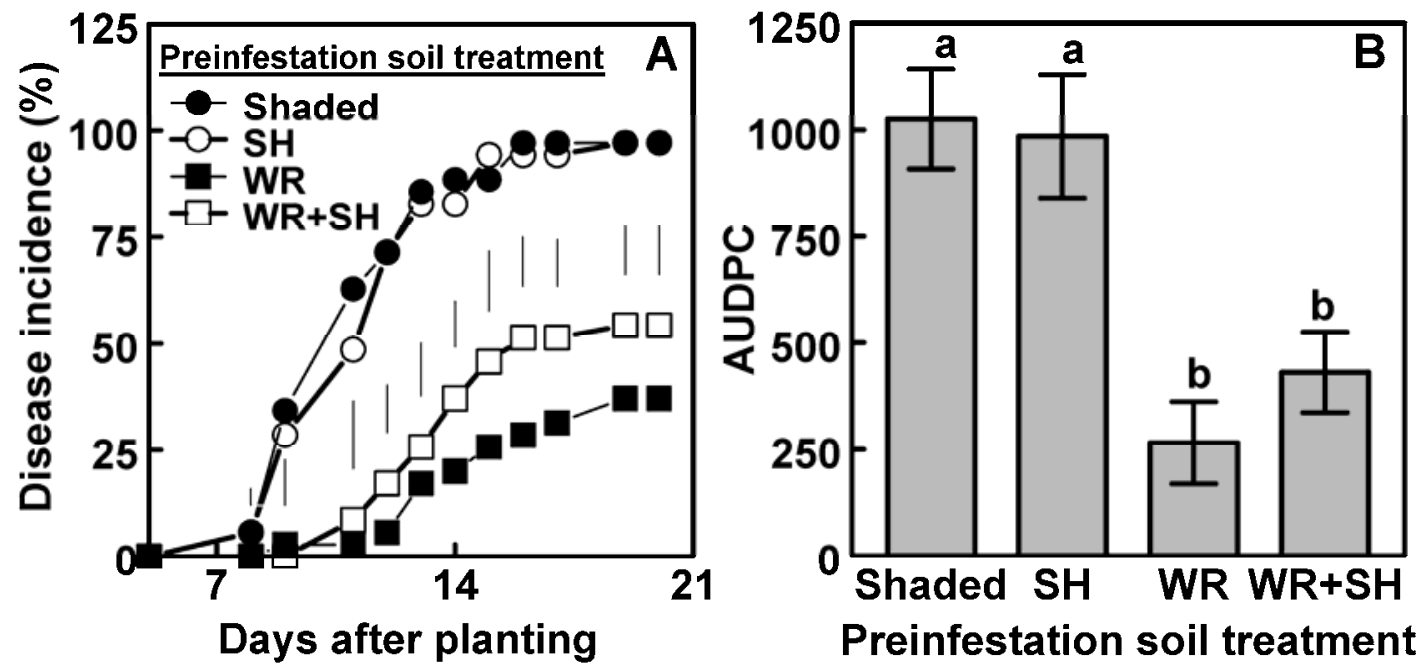

Fig. 1. Effect of wild rocket (WR) amendment and soil solarization (SH) on A, disease incidence in Fusarium crown and root rot-inoculated cucumber transplants in Rehovot soil or B, area under the disease progress curve (AUDPC). Cucumber seedlings were inoculated before planting with macroconidia of Fusarium oxysporum $\mathrm{f}$. sp. radicis cucumerinum at $10^{5} \mathrm{CFU} / \mathrm{ml}$. Soil was either irrigated; mulched and shaded for 28 days (during July 2009) under field conditions (Shaded); or irrigated, mulched, and solarized for 28 days. Soil was amended with dry WR at a rate of $1 \%$ (wt/wt) before incubation. Vertical bars indicate average standard deviations, and values followed by a different letter are significantly different according to Tukey's studentized range (honestly significant difference) test at $P \leq 0.05$. 
pressiveness was considered long term because it was evident 34 months after soil treatment and after successive plantings (Figs. 2 and 3).

Disease suppressiveness in soil inoculated with chlamydospores. Chlamydospores produced in infested peat (as an additional type of $F$. oxysporum f. sp. radicis-cucumerinum inoculum) were mixed with the tested soils at various inoculum concentrations before seeding with cucumber. Emergence of the cucumber seedlings (70 to $80 \%$ ) was not affected by $F$. oxysporum f. sp. radicis-cucumerinum, regardless of the soil treatment. Diseased plants showed symptoms after 9 to 11 days at the highest inoculum concentrations. The suppressiveness in WR-amended soil was more pronounced at the low rate of inoculum, in which disease symptoms first appeared after 20 days, but was still significant at the highest rate of chlamydospore inoculum (Table 4). Solarization significantly increased AUDPC relative to nonsolarized soils at the two highest inoculum concentrations in the first sowing but had no significant effect in the second planting. In three of six cases, combining solarization with WR significantly increased disease incidence relative to WR alone. Amendment with WR significantly reduced AUDPC only in nonsolarized soils (Table 4).

Induced suppressiveness in different soils. The suppressive capacity of WR amendment was evident in all three tested soils (Fig. 4). The nonamended soils from Bet Dagan and En Tamar expressed higher natural suppressiveness than the Rehovot soil. However, when amended with WR, the three soils exhibited similar levels of suppressiveness (Fig. 4). Disease suppressiveness was also sustained in all three soils during the second consecutive inoculation

Table 3. Effect of wild rocket-amended soil (WR) and Fusarium crown and root rot inoculation on cucumber root and shoot dry weight ${ }^{\mathrm{x}}$

\begin{tabular}{lccccc}
\hline & \multicolumn{2}{c}{ Root dry weight (g/plant) $^{\mathbf{y}}$} & & \multicolumn{2}{c}{ Shoot dry weight (g/plant) } \\
\cline { 2 - 3 } \cline { 5 - 6 } Soil & Noninoculated & Inoculated $^{\mathbf{z}}$ & & Noninoculated & Inoculated \\
\hline Nonamended & $0.0479 \mathrm{Ba}$ & $0.0467 \mathrm{Ba}$ & & $0.1567 \mathrm{Ba}$ & $0.1100 \mathrm{Ba}$ \\
WR & $0.0777 \mathrm{Ab}$ & $0.1159 \mathrm{Aa}$ & & $0.3786 \mathrm{Aa}$ & $0.3333 \mathrm{Aa}$ \\
\hline
\end{tabular}

${ }^{x}$ Shading of Rehovot soil under field conditions was conducted for 28 days during July 2009 . WR was applied to the soil at $10 \mathrm{~g} / \mathrm{kg}(1 \%$, wt $/ \mathrm{wt})$. Cucumber seedlings were inoculated with Fusarium oxysporum f. sp. radicisсиситеrinum macroconidia at $10^{5} \mathrm{CFU} / \mathrm{ml}$ and planted in the previously treated soils. Shoot and root weights were recorded on day 22 after planting. Different uppercase letters denote significant difference in amendment level; different lowercase letters denote significant difference in inoculation level, according to analysis of variance of the root or shoot dry weight, Tukey's studentized range (honestly significant difference) test at $P \leq 0.05$.

${ }^{\mathrm{y}}$ For root dry weight, inoculation-amendment $F$ value $=8.9 ; P>F<0.0054$.

${ }^{\mathrm{z}}$ For shoot dry weight, inoculation $F$ value $=7.8 ; P>F=0.0087$; amendment $F$ value $=182.9 ; P>F<0.0001$; inoculation-amendment interaction was not significant.

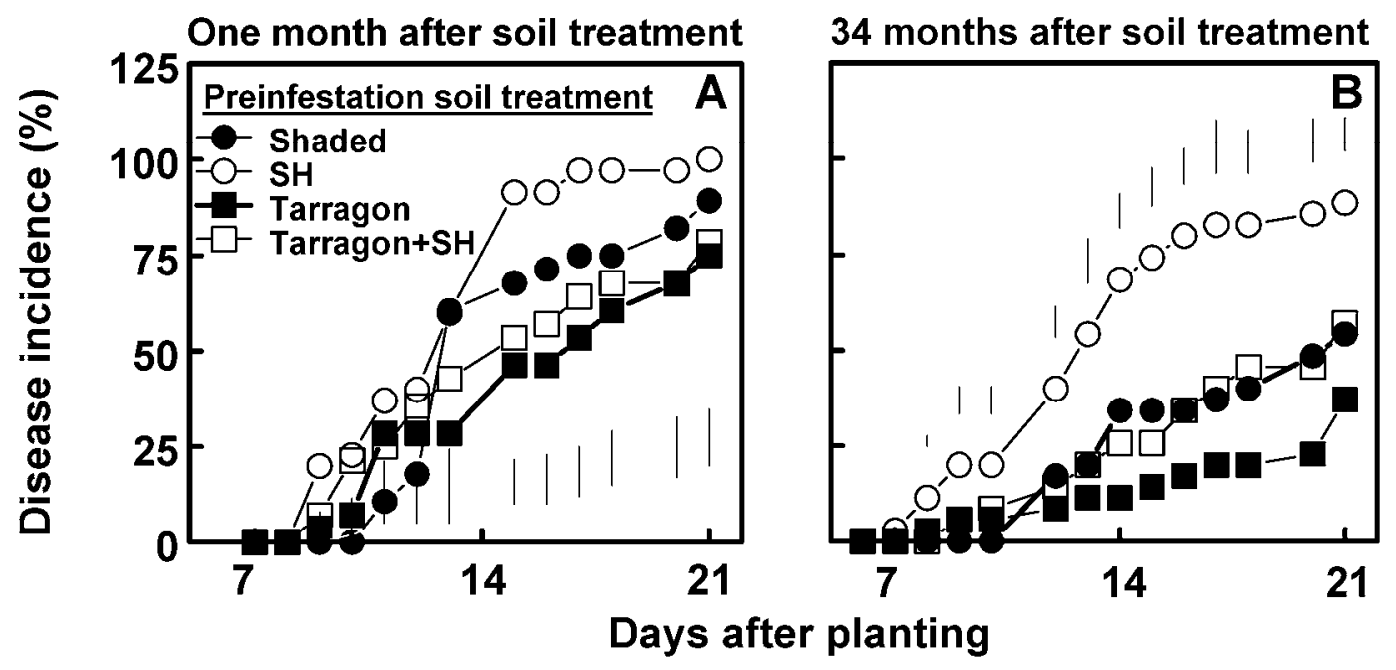

Fig. 2. Effect of tarragon amendment and solarization (SH) on Fusarium crown and root rot in inoculated cucumber transplants in Rehovot soil $\mathbf{A}$, immediately after incubation with tarragon or B, 34 months afterward. Soil was either irrigated, mulched, and shaded for 4 weeks under field conditions (Shaded) or irrigated, mulched, and solarized for 28 days (during July 2009). Soil was amended with dry tarragon at a rate of $1 \%$ (wt/wt) before incubation. Cucumber seedlings were inoculated before planting with macroconidia of Fusarium oxysporum f. sp. radicis cucumerinum at $1.5 \times 10^{5}$ or $1 \times 10^{5} \mathrm{CFU} / \mathrm{ml}$ in A and B, respectively. Vertical bars indicate average standard deviations. Amendment and solarization main effects were significant by analysis of variance of the area under the disease progress curve. First suppressiveness test: amendment $F$ value $=12.36, P>F=$ 0.0038; solarization $F$ value $=7.17, P>F=0.0190$. Second suppressiveness test: amendment $F$ value $=17.65, P>F=0.0007 ;$ solarization $F$ value $=15.44, P>F=0.0012$.

Table 2. Statistical analysis of variance (ANOVA) of area under the disease progress curve (AUDPC) of Fusarium crown and root rot in inoculated cucumber seedlings which were grown in amended Rehovot soil ${ }^{\mathrm{y}}$

\begin{tabular}{|c|c|c|c|c|c|c|c|}
\hline \multirow[b]{3}{*}{ Experiment } & \multirow[b]{3}{*}{ Soil treatment ${ }^{\mathrm{z}}$} & \multicolumn{6}{|c|}{ ANOVA of AUDPC $(P<0.05)$} \\
\hline & & \multicolumn{3}{|c|}{ AUDPC, first planting } & \multicolumn{3}{|c|}{ AUDPC, second planting } \\
\hline & & df & $F$ value & $P>F$ & df & $F$ value & $P>F$ \\
\hline 1 & Amendment & 3 & 44.38 & $<0.0001$ & 3 & 3.12 & 0.0397 \\
\hline 1 & Solarization & 1 & 5.89 & 0.0210 & 1 & 3.16 & 0.0847 \\
\hline 1 & Amendment $\times$ solarization & 3 & 1.48 & 0.2398 & 3 & 1.60 & 0.2084 \\
\hline 2 & Amendment & 3 & 15.02 & $<0.0001$ & 3 & 19.90 & $<0.0001$ \\
\hline 2 & Solarization & 1 & 10.76 & 0.0026 & 1 & 0.01 & 0.9339 \\
\hline 2 & Amendment $\times$ solarization & 3 & 2.28 & 0.0986 & 3 & 0.84 & 0.4813 \\
\hline
\end{tabular}

y Cucumber seedlings were inoculated with Fusarium oxysporum f. sp. radicis-cucumerinum macroconidia at $1.5 \times 10^{5} \mathrm{CFU} / \mathrm{ml}$ and planted in the previously treated soils.

${ }^{\mathrm{z}}$ Solarization or shading under field conditions was conducted for 28 days during July 2005. Soil was amended with different plant residues before planting. In each experiment, different amendments were tested. In the first experiment, amendments were coriander, peppermint, and rosemary. In the second experiment, amendments were broccoli, cauliflower, and sage. 
and planting cycle in the same pots, with the Bet Dagan soil being the most suppressive (Fig. 4).

\section{Discussion}

In the present study, we focused on soil suppressiveness (i.e., the reduction in disease level when a pathogen is introduced into a soil after it has been amended and incubated with various OAs or disinfested by solarization) (Figs. 1 and 2; Tables 1 and 2). Direct impact on the pathogen and disease reduction which results from direct action on the pathogen during the incubation process was not evaluated in these studies. These aspects have been discussed in previous publications $(28,29)$. The suppressive capacity of soil is not necessarily related to direct pathogen control, which occurs during the incubation process and has been documented in numerous studies dealing with disease control by OAs $(4,32,43,49)$. The combination of solarization and OAs, while showing an added value in pest control $(20,28)$, does not provide higher suppressiveness potential. The present study demonstrates that crop residues alone provide the most significant suppressive effect. Apparently, the mechanisms involved in the two processes, (i.e., pest control using solarization and OAs and disease suppressiveness) may not be related, because solarization had no significant effect on suppressiveness in the repetitive inoculated planting cycles (Fig. 3).

The evolution of soil suppressiveness to $F$. oxysporum f. sp. radicis-cucumerinum, as reflected in reduced disease incidence and AUDPC, was evident in three tested soils (Fig. 4), with two types of inoculum (Fig. 1; Table 4) and various OAs (Tables 1 and 2; Figs. 1 and 2). Disease suppressiveness was reflected in the OAtreated soil by a delay in disease onset and 20 to $80 \%$ lower plant mortality (Figs. 1-4), phenomena which are associated with disease suppressiveness $(25,47,51)$. Moreover, a long-term effect (lasting 34 months [Figs. 2 and 3] or with repeated plantings [Fig. 3 ; Tables 1 and 2]) was also recorded, further indicating the evolution of soil suppressiveness. Soil suppressiveness against $F$. oxysporum $\mathrm{f}$. sp. radicis-cucumerinum, as also manifested with other formae specialis of Fusarium, was demonstrated following consecutive inoculation and cucumber plantings in compost-amended soil by Yogev et al. (51). The long-term effect of OAs in producing suppressiveness, as observed in our study, was more pronounced than that reported previously in other studies $(38,52)$. Yulianti et al. (52) suggested that an increase in microbial activity following the decomposition of WR or B. nigra manures plays a dominant role in suppressing Rhizoctonia solani. Motisi et al. (37) found a suppressive effect using $B$. juncea which lasted for 13 days, whereas the predominant glucosinolates, which may have a direct effect on the pathogen, were hydrolyzed in less than 3 days.

Most of the plant residues tested for suppressiveness had been previously found effective in controlling soilborne pathogens or to have the potential to control pathogens as a result of the generation of biotoxic molecules (e.g., essential oils or glucosinolates; $3,4,13,32,40,41,49)$. In the present study, the decomposition of OAs in soil prior to infestation was carried out under aerobic conditions (28). Generally, under such conditions, the effect of decomposition products of plant residues on the pathogen population is variable. In contrast, under anaerobic conditions, a significant reduction in pathogen populations was found regardless of the type of residues incorporated (6). The decomposition of OAs under anaerobic conditions, although directly controlling soilborne pathogens, did not induce soil suppressiveness in some trials while it did in others $(4,21)$, similar to the variable effects seen when using solarization. This further supports the hypothesis that the native microflora play an important role in developing suppressiveness $(12,25,36)$.

The potential of different plant residues as well as composts to induce soil suppressiveness against plant diseases has been documented $(30,34,38,42)$. In most cases, it was correlated with antagonistic or competitive microbial activity. Soil suppressiveness will persist for longer periods if the OA is functioning through enhanced activity of the resident soil microbial community rather than through the introduction of a novel active community (34). However, this activity may be nullified by antimicrobial means such as soil disinfestation (2).

In the present study, the effect of soil solarization, alone or combined with OAs, on soil suppressiveness was variable (Tables 1, 2, and 4; Fig. 2). This is in contrast to previous studies, in which solarization-induced soil suppressiveness toward various pathogens was reported $(15,22,27,33)$. Greenberger et al. (22) found that solarization increased suppressiveness to $F$. oxysporum f. sp. lycopersici in 8 of 12 tested soils. In contrast, Mihail and Alcorn (35) found no reduction in a population of Macrophomina phaseolina following solarization, probably due to the treatment's elimination of antagonistic or competitive microflora in the soil. The inconsistency in suppressiveness following solarization can be related to differences within a given soil or among soils from different loca-

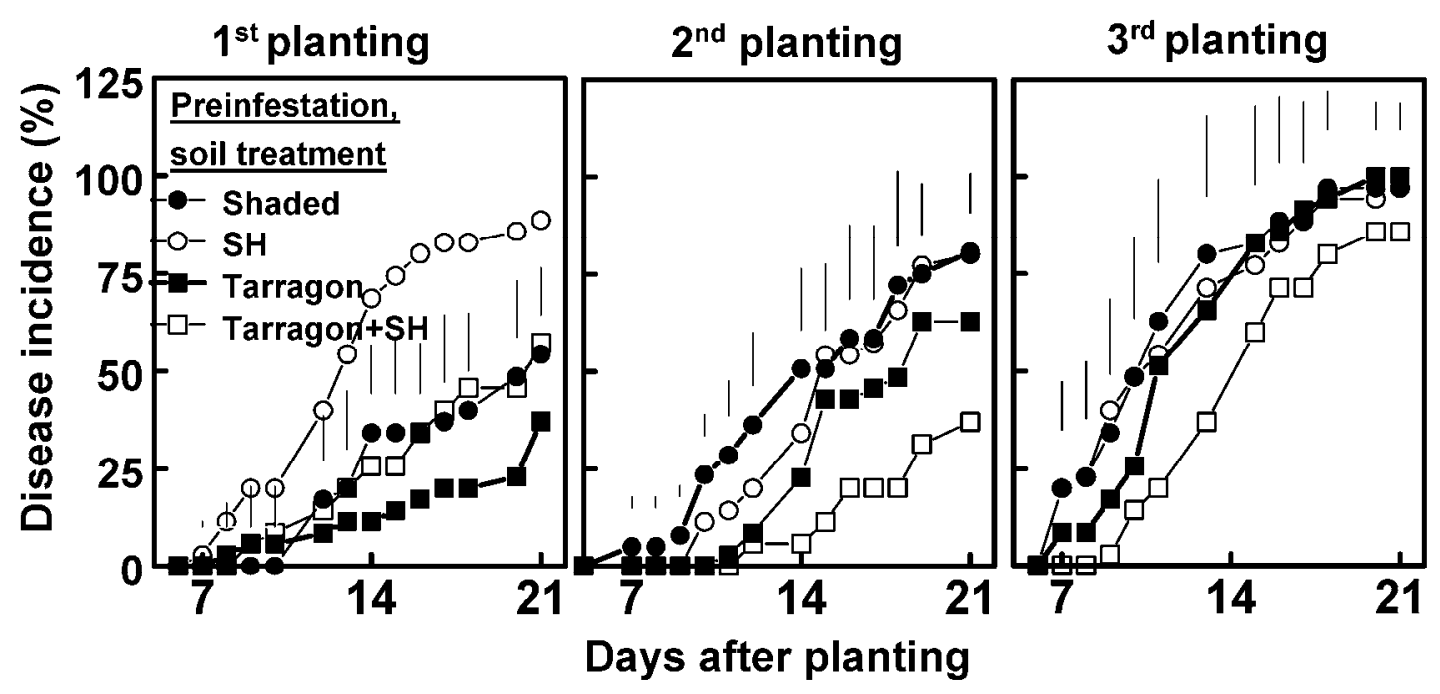

Fig. 3. Effect of tarragon amendment and solarization (SH) on Fusarium crown and root rot of cucumber transplants in Rehovot soil. Three repeat-inoculated plantings were carried out, 34 months after soil treatment. Soil was either irrigated, mulched, and shaded for 28 days under field conditions (Shaded) or irrigated, mulched, and solarized for 28 days. Soil was amended with dry tarragon at a rate of $1 \%$ (wt/wt) before incubation. Cucumber seedlings were inoculated before each planting with macroconidia of Fusarium oxysporum f. sp. radicis cucumerinum at $1 \times 10^{5} \mathrm{CFU} / \mathrm{ml}$. Vertical bars indicate average standard deviations. Amendment and solarization main effects were significant by analysis of variance of the area under the disease progress curve of each inoculated planting. First planting: amendment $F$ value $=17.65, P>F=0.0007$; solarization $F$ value $=15.44, P>F=0.0012$. Second planting: amendment $F$ value $=19.0, P>F=0.0005$; solarization effect was not significant. Third planting: amendment $F$ value $=6.39, P>F=0.0224$; solarization effect was not significant. 
tions. For example, when soil samples were taken from different locations of Rehovot soil (22), one sample of solarized soil increased suppressiveness, whereas another sample of this soil slightly reduced it. Deadman et al. (14) found that solarization improved soil suppressiveness when combined with OAs. Solarization of cabbageamended soil reduced the inoculum potential of Pythium aphanidermatum during the following winter growing season, leading to a $40 \%$ reduction in damping-off of cucumber plants

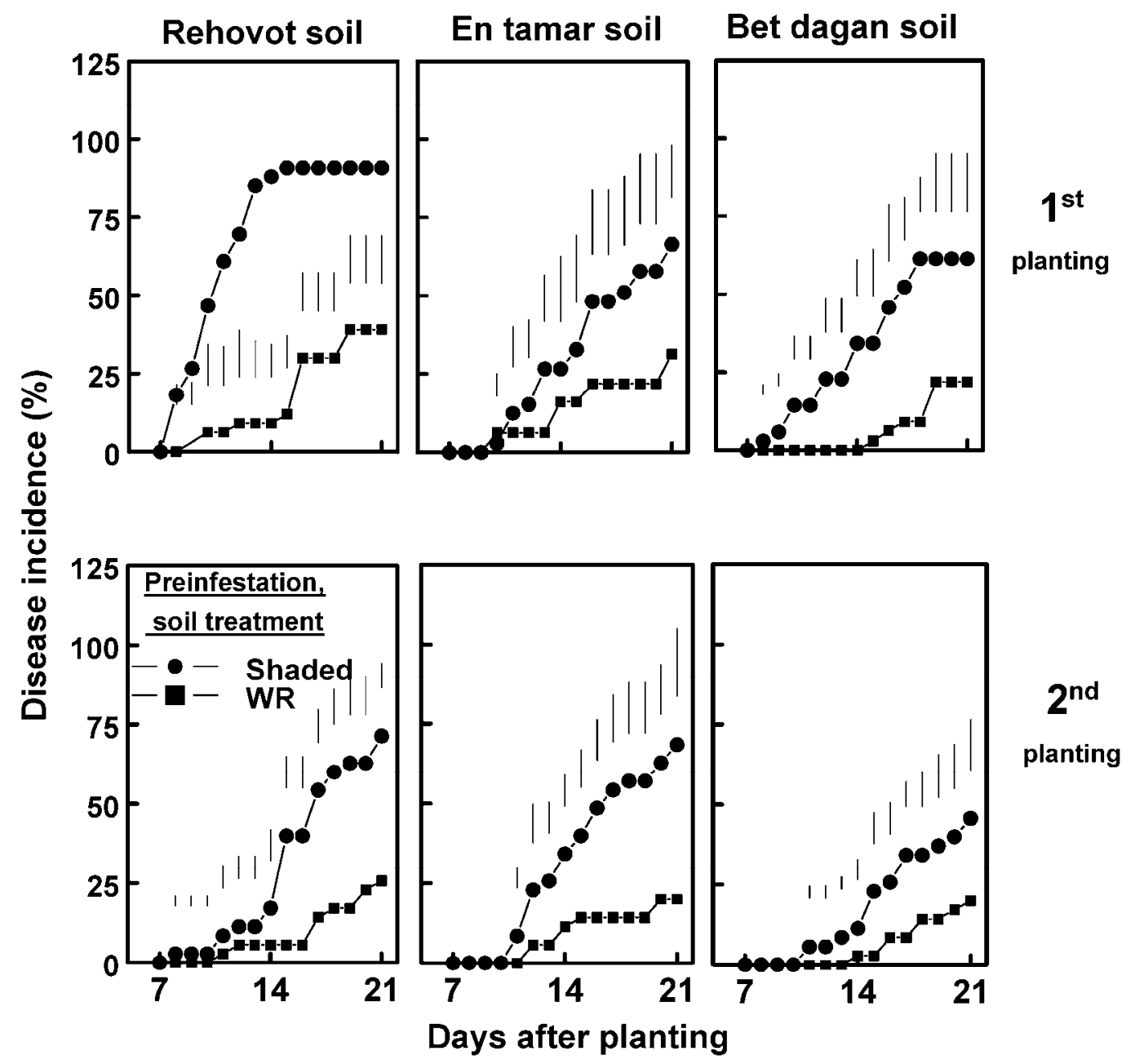

Fig. 4. Effect of wild rocket (WR) amendment on Fusarium crown and root rot of cucumber transplants in Rehovot, En Tamar, and Bet Dagan soils. Soil was irrigated, mulched, and shaded for 28 days (during July 2009) under field conditions or amended with dry WR at a rate of $1 \%$ (wt/wt) before incubation. Two repeat-inoculated plantings were carried out. Cucumber seedlings were inoculated before each planting with macroconidia of Fusarium oxysporum f. sp. radicis cucumerinum at $1.5 \times 10^{5} \mathrm{CFU} / \mathrm{ml}$. Vertical bars indicate average standard deviations. In the first inoculated planting, the soil-amendment interaction was significant by analysis of variance (ANOVA) of the area under the disease progress curve (AUDPC): $F$ value $=7.77, P>F=0.0025$. In the second inoculated planting, soil and amendment main effects were significant by ANOVA of the AUDPC: soil $F$ value $=5.46, P>F$ $=0.0111$. AUDPC in Bet Dagan soil significantly decreased compared with the other soils. Amendment main effect $F$ value $=67.03, P>F<0.0001$.

Table 4. Effect of wild rocket amendment (WR) and solarization on area under the disease progress curve (AUDPC) of Fusarium crown and root rot in cucumber which was sown or planted in a Rehovot soil inoculated with chlamydospores of Fusarium oxysporum f. sp. radicis-cucumerinum

\begin{tabular}{|c|c|c|c|c|c|}
\hline \multirow[b]{3}{*}{ Chlamydospores $^{\mathrm{y}}$} & \multirow[b]{3}{*}{ Solarization $^{\mathrm{z}}$} & \multicolumn{4}{|c|}{ Planting ${ }^{x}$} \\
\hline & & \multicolumn{2}{|c|}{ First (sowing) } & \multicolumn{2}{|c|}{ Second (planting) } \\
\hline & & Nonamended & WR & Nonamended & WR \\
\hline $4.075 \times 10^{4}$ & Shaded & $386.8 \mathrm{~B}$ & $53.0 \mathrm{C}$ & $775.0 \mathrm{AB}$ & $452.4 \mathrm{~B}$ \\
\hline $4.075 \times 10^{4}$ & Solarized & $717.9 \mathrm{~B}$ & $417.7 \mathrm{BC}$ & $368.6 \mathrm{~B}$ & $785.7 \mathrm{~B}$ \\
\hline $8.15 \times 10^{4}$ & Shaded & $479.2 \mathrm{~B}$ & $138.5 \mathrm{C}$ & $835.7 \mathrm{AB}$ & $527.1 \mathrm{~B}$ \\
\hline $8.15 \times 10^{4}$ & Solarized & $1,212.0 \mathrm{~A}$ & $707.2 \mathrm{AB}$ & $1,292.9 \mathrm{~A}$ & $920.0 \mathrm{~B}$ \\
\hline $2.375 \times 10^{5}$ & Shaded & $601.7 \mathrm{~B}$ & $409.3 \mathrm{BC}$ & $1,040.0 \mathrm{~A}$ & $461.7 \mathrm{~B}$ \\
\hline $2.375 \times 10^{5}$ & Solarized & $1,659.7 \mathrm{~A}$ & $1,012.7 \mathrm{~A}$ & $1,257.1 \mathrm{~A}$ & $1,635.7 \mathrm{~A}$ \\
\hline $\operatorname{MSD}(P<0.05)$ & $\ldots$ & 478.7 & 429.5 & 604.1 & 705.4 \\
\hline
\end{tabular}

${ }^{\mathrm{x}}$ In the first suppressiveness test, cucumber seed were sown in the tested soils; in the second (repeat) planting, cucumber seedlings were planted in the same soils without additional inoculation. Cucumber was grown for 28 days in each cycle. AUDPC means within a column followed by different letters are significantly different according to Tukey's studentized range (honestly significant difference) test at $P \leq 0.05$. Amendment main effect and the chlamydospore concentrationsolarization interaction were significant by analysis of variance (ANOVA) of the AUDPC: amendment $F$ value $=41.78, P>F<0.0001$; chlamydospore concentration-solarization $F$ value $=5.66, P>F=0.0063$. Inoculum concentration-solarization and solarization-amendment interactions were significant by ANOVA of the AUDPC: chlamydospore concentration-solarization $F$ value $=6.17, P>F=0.0042$; solarization-amendment $F$ value $=9.80, P>F=0.0030$.

${ }^{y}$ Chlamydospore concentration. MSD = minimum significant difference.

${ }^{\mathrm{z}}$ Solarization or shading under field conditions was conducted for 28 days during July 2008 . WR was applied to the soil at $10 \mathrm{~g} / \mathrm{kg}(1 \%$, wt/wt). 
compared with solarization alone, although inoculum density was similar in both treatments. In that study, solarization alone did not contribute to suppressiveness. It is also possible that soil suppressiveness following $\mathrm{OA}$ and solarization depends on the challenged pathogen in a given soil (in this study, F. oxysporum f. sp. radicis-cucumerinum).

The level of suppressiveness induced by WR was reduced by increased inoculum density (Table 4). Similarly, infection rates of Fusarium wilt of pea in chitin-amended soil were found to be directly correlated with chlamydospore density, in comparison with nonamended controls (23). Smith and Snyder (44) distinguished suppressive soils by the rate of chlamydospores needed to induce Fusarium wilt on sweet potato. They found that, in a suppressive soil, the inoculum density required to cause disease was twice that in conducive or noncultivated-suppressive soils. In addition, a higher percentage of chlamydospores of saprophytic Fusarium spp. germinated in wilt-suppressive soils than did chlamydospores of the tested pathogens (45).

The induced suppressiveness in OA-amended soils may be related to chemical or physical changes in the soil which, in turn, affect plant response to pathogens (10), or to stimulation of beneficial microbes which either directly affect the pathogens or induce resistance in the plant (17). Induced soil suppressiveness is only one component in disease management by OAs or solarization, and the other components (e.g., reduction in pathogen population and in its capacity to induce disease) should also be considered.

\section{Acknowledgments}

This research was partially supported by grants from the Chief Scientist of the Ministry of Agricultural and Rural Development. We thank the staff of the Laboratory for Pest Management Research for their technical assistance; M. Alpert and YAAF Corporation (Mehola, Israel) for providing fresh herbs; $\mathrm{H}$. Voet for advice in the statistical analysis; and Y. Gotlieb and the staff of the Hebrew University Experimental Farm for their cooperation.

\section{Literature Cited}

1. Abawi, G. S., and Widmer, T. L. 2000. Impact of soil health management practices on soilborne pathogens, nematodes and root diseases of vegetable crops. Appl. Soil Ecol. 15:37-47.

2. Baker, K. F. 1987. Evolving concepts of biological control of plant pathogens. Annu. Rev. Phytopathol. 25:67-85.

3. Bennett, R. N., Rosa, E. A. S., Mellon, F. A., and Kroon, P. A. 2006. Ontogenic profiling of glucosinolates, flavonoids and other secondary metabolites in Eruca sativa (salad rocket), Diplotaxis erucoides (wall rocket), Diplotaxis tenuifolia (wild rocket), and Bunias orientalis (Turkish rocket). J. Agric. Food Chem. 54:4005-4015.

4. Blok, W. J., Larmes, J. G., Thermorshuizen, A. J., and Bollen, G. J. 2000. Control of soilborne plant pathogens by incorporating fresh organic amendments followed by tarping. Phytopathology 90:253-259.

5. Boehm, M. J., Tianyun, W. U., Stone A. G., Kraakman, B., Iannotti, D. A., Wilson, G. E., Madden L. V., and Hoitink, H. A. J. 1997. Cross-polarized magic-angle spinning ${ }^{13} \mathrm{C}$ nuclear magnetic resonance spectroscopic characterization of soil organic matter relative to culturable bacterial species composition and sustained biological control of Pythium root rot. Appl. Environ. Microbiol. 63:162-168.

6. Bonanomi, G., Antignani, V., Pane C., and Scala, F. 2007. Suppression of soilborne fungal diseases with organic amendments. J. Plant Pathol. 89:311324.

7. Borrero, C., Trillas, M. I., Ordovás, J., Tello, J. C., and Avilés, M. 2004. Predictive factors for the suppression of Fusarium wilt of tomato in plant growth media. Phytopathology 94:1094-1101.

8. Brown, P. D., and Morra, M. J. 1997. Control of soilborne plant pests using glucosinolate-containing plants. Adv. Agron. 61:167-231.

9. Campbell, C. L., and Madden, L. V. 1990. Introduction to Plant Disease Epidemiology. John Wiley and Sons, New York.

10. Chen, Y., Gamliel, A., Stapleton, J. J., and Aviad, A. 1991. Chemical, physical, and microbial changes related to plant growth in disinfested soils. Pages 103-130 in: Soil Solarization. J. Katan, and J. E. DeVay, eds. CRC Press, Boca Raton, FL.

11. Cohen, M. F., Yamasaki, H., and Mazzola, M. 2005. Brassica napus seed meal soil amendment modifies microbial community structure, nitric oxide production and incidence of Rhizoctonia root rot. Soil Biol. Biochem. 37:1215-1227.

12. Cook, R. J., and Baker, R. F. 1983. The Nature and Practice of Biological Control of Plant Pathogens. American Phytopathological Society, St. Paul, $\mathrm{MN}$.

13. Daferera, D. J., Ziogas, B. N., and Polissiou, M. G., 2003. The effectiveness of plant essential oils on the growth of Botrytis cinerea, Fusarium sp. and
Clavibacter michiganensis subsp. michiganensis. Crop Prot. 22:39-44.

14. Deadman M., Al Hasani, H., and Al Sa'di A. 2006. Solarization and biofumigation reduce Pythium aphanidermatum induced damping-off and enhance vegetative growth of greenhouse cucumber in Oman. J. Plant Pathol. 88:335-337.

15. Freeman, S., Sztejnberg, A., Shabi, E., and Katan, J., 1990. Long-term effect of soil solarization for the control of Rosellinia necatrix in apple. Crop Prot. 9:312-316.

16. Gamliel, A., Austerweil, M., and Kritzman, G. 2000. Nonchemical approach to soilborne pest management-organic amendments. Crop Prot. 19:847-853.

17. Gamliel, A., and Katan, J. 1991. Involvement of fluorescent pseudomonads and other microorganisms in increased growth response of plants in solarized soils. Phytopathology 81:494-502.

18. Gamliel, A., and Katan, J. 1993. Suppression of major and minor pathogens by fluorescent pseudomonads in solarized and non-solarized soils. Phytopathology 83:68-75.

19. Gamliel, A., and Katan, J. 2009. Control of plant disease through soil solarization. Pages 196-220 in: Disease Control in Crops. D. Walters, ed. Blackwell Publishing Ltd., Oxford.

20. Gamliel, A., and Stapleton, J. J. 1993. Effect of chicken compost or ammonium phosphate and solarization on pathogen control, rhizosphere microorganisms, and lettuce growth. Plant Dis. 77:886-891.

21. Goud, J.-K. C., Termorshuizen, A. J., Blok, W. J., and van Bruggen, A. H. C. 2004. Long-term effect of biological soil disinfestation on Verticillium wilt. Plant Dis. 88:688-694.

22. Greenberger, A., Yogev, A., and Katan, J. 1987. Induced suppressiveness in solarized soils. Phytopathology 77:1663-1667.

23. Guy, S. O., and Baker R. 1977. Inoculum potential in relation to biological control of Fusarium wilt of peas. Phytopathology 67:72-78.

24. Hoitink, H. A. J. 1980. Composted bark, a lightweight growth medium with fungicidal properties. Plant Dis. 64:142-147.

25. Hornby, D. 1983. Suppressive soils. Annu. Rev. Phytopathol. 21:65-85.

26. Janvier, C., Villeneuve, F., Alabouvette, C., Edel-Hermann, V., Mateille, T. and Steinberg, C. 2007. Soil health through soil disease suppression: which strategy from descriptors to indicators? Soil Biol. Biochem. 39:1-23.

27. Kassaby, F. Y. 1985. Solar-heating soil for control of damping-off diseases. Soil Biol. Biochem. 17:429-434.

28. Klein, E., Katan, J., Austerweil, M., and Gamliel, A. 2007. Controlled laboratory system to study soil solarization and organic amendment effects on plant pathogens. Phytopathology 97:1476-1483.

29. Klein, E., Katan, J., and Gamliel, A. Combining residues of herb crops with soil heating for control of soilborne pathogens in a controlled laboratory system. Crop Prot. 30:368-374.

30. Kuter, G. A., Nelson, E. B., Hoitink, H. A. J., and Madden, L. V. 1983. Fungal populations in container media amended with composted hardwood bark suppressive and conducive to Rhizoctonia damping-off. Phytopathology $73: 1450-1456$

31. Lazarovits, G., Conn, K. L., Abbasi, P. A., and Tenuta, M. 2005. Understanding the mode of action of organic soil amendments provides the way for improved management of soilborne plant pathogens. Proc. VIth IS on Chemical and Non-Chemical Soil and Substrate Disinfestation. A. Vanachter, ed. Acta Hortic. 698:215-224.

32. Lodha, S., Sharma, S. K., and Aggarwal, R. K. 1997. Solarization and natural heating of irrigated soil amended with cruciferous residues for improved control of Macrophomina phaseolina. Plant Pathol. 46:186-190.

33. Martyn, R. D., and Hartz, T. K. 1986. Use of soil solarization to control Fusarium wilt of watermelon. Plant Dis. 70:762-766.

34. Mazzola, M. 2004. Assessment and management of soil microbial community structure for disease suppression. Annu. Rev. Phytopathol. 42:35-59.

35. Mihail, J. D., and Alcorn, S. M. 1984. Effects of soil solarization on Macrophomina phaseolina and Sclerotium rolfsii. Plant Dis. 68:156-159.

36. Momma, N., Momma, M., and Kobara, Y. 2010. Biological soil disinfestation using ethanol: effect on Fusarium oxysporum f. sp. lycopersici and soil microorganisms. J. Gen. Plant Pathol. 76:336-344.

37. Motisi, N., Monfort, F., Dore, T., Romillac, N., and Lucas, P. 2009. Duration of control of two soilborne pathogens following incorporation of above- and below-ground residues of Brassica juncea into soil. Plant Pathol. 58:470-478.

38. Noble, R., and Coventry, E. 2005. Suppression of soil-borne plant diseases with compost: a review. Biocontrol Sci. Technol. 15:3-20.

39. Pankhurst, C. E., McDonald, H. J., Hawke, B. G., and Kirkby, C. A. 2002. Effect of tillage and stubble management on chemical and microbiological properties and the development of suppression towards cereal root disease in soils from two sites in NSW, Australia. Soil Biol. Biochem. 34:833-840.

40. Ploeg, A. T., and Stapleton J. J. 2001. Glasshouse studies on the effects of time, temperature and amendment of soil with broccoli plant residues on the infestation of melon plants by Meloidogyne incognita and M. javanica. Nematology 3:855-861.

41. Postma, J., Scheper, R. W. A., and Schilder, M. T. 2010. Effect of successive cauliflower plantings and Rhizoctonia solani AG 2-1 inoculations on disease suppressiveness of suppressive and conducive soil. Soil Biol. Biochem. 42:804-812.

42. Raaijmakers, J. M., Paulitz, T. C., Steinberg, C., Alabouvette, C., and 
Moënne- Loccoz, Y. 2009. The rhizosphere: a playground and battlefield for soilborne pathogens and beneficial microorganisms. Plant Soil 321:341361.

43. Ramirez-Villapudua, J., and Munnecke, D. E. 1988. Effect of solar heating and soil amendments of cruciferous residues on Fusarium oxysporum f. sp. conglutinans and other organisms. Phytopathology 78:289-295.

44. Smith, S. N., and Snyder, W. C. 1971. Relationship of inoculum density and soil types to severity of Fusarium wilt of sweet potato. Phytopathology 61:1049-1051

45. Smith, S. N., and Snyder, W. C. 1972. Germination of Fusarium oxysporum chlamydospores in soils favorable and unfavorable to wilt establishment. Phytopathology 62:273-277.

46. Stapleton, J. J., Summers, C. G., Mitchell, J. P., and Prather T. S. 2010. Deleterious activity of cultivated grasses (Poaceae) and residues on soilborne fungal, nematode and weed pests. Phytoparasitica 38:61-69.

47. Steinberg, C., Edel-Hermann, V., Alabouvette, C., and Lemanceau, P. 2006. Soil suppressiveness to plant diseases. Pages 455-477 in: Modern Soil Microbiology, 2nd ed. J. D. Van Elsas, J. K. Jansson, and J. T. Trevors, eds. CRC Press, Boca Raton, FL.
48. Stone, A. G., Scheuerell, S. J., and Darby, H. M. 2004. Suppression of soilborne diseases in field agricultural systems: organic matter management, cover cropping, and other cultural practices. Pages 131-177 in: Soil Organic Matter in Sustainable Agriculture. F. Magdoff and R. Weil, eds. CRC Press, Boca Raton, FL.

49. Subbarao, K. V., Hubbard, J. C., and Koike, S. T. 1999. Evaluation of broccoli residue incorporation into field soil for Verticillium wilt control in cauliflower. Plant Dis. 83:124-129.

50. Triky-Dotan, S., Austerweil, M., Steiner, B., Peretz-Alon, Y., Katan, J., an Gamliel, A. 2007. Generation and dissipation of methyl isothiocyanate in soils following metam sodium fumigation: impact on Verticillium control and potato yield. Plant Dis. 91:497-503.

51. Yogev, A., Raviv, M., Hadar, Y., Cohen, R., and Katan, J. 2006. Plant wastebased composts suppressive to diseases caused by pathogenic Fusarium oxysporum. Eur. J. Plant Pathol. 116:267-278.

52. Yulianti, T., Sivasithamparam, K., and Turner, D. 2007. Saprophytic and pathogenic behaviour of $R$. solani AG2-1 (ZG-5) in a soil amended with Diplotaxis tenuifolia or Brassica nigra manures and incubated at different temperatures and soil water content. Plant Soil 294:277-289. 